\title{
KAMENNÝ ŽARNOV Z OPONICKÉHO HRADU A ÚVAHY O FUNKCII MLECÍCH ZARIADENÍ NA STREDOVEKÝCH A NOVOVEKÝCH HRADOCH ${ }^{1}$
}

\author{
Dominik Repka - Zuzana Borzová - Stanislava Blahová
}

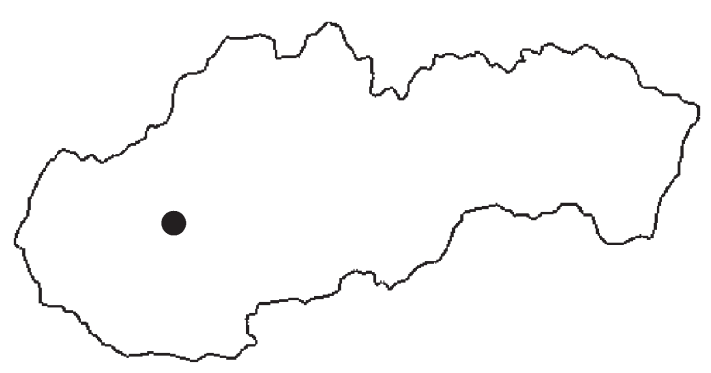

DOI: https://doi.org/10.31577/szausav.2021.68.6

Keywords: Oponice castle, quern stone, millstones, castles, Middle Ages, Post-medieval period, La Tène period

The quern stone from the Oponice castle and discussion on the function of grinding tools at medieval and postmedieval castles

Rotary mills or their stone parts, i. e. quern stones and millstones, occur only exceptionally at medieval and postmedieval castles - unlike the rural environment. The quern stone discovered in 2018 in the northern part of the castle courtyard near the eastern wall of Oponice castle's barbacan (Topol'čany district) is one of such exemplars. By its shape and size, we can assume that originally it was a La Tène quern. It was secondarily adapted and used as the rotating part of a hand mill probably during the castle's existence. The objective of our article is to explain the function of the unusual quern stone at Oponice castle and use of grinding tools at medieval and post-medieval castles.

\section{ÚVOD}

Oponický hrad je situovaný v juhozápadnej časti Slovenska, približne 2,5 km juhovýchodne od intravilánu obce Oponice, okr. Topolčany. Hrad bol na základe výsledkov výskumu postavený ako väčšina kamenných uhorských hradov, a to v priebehu 2. polovice 13. storočia. Slúžit mal pravdepodobne ako pevnost' dohliadajúca na obchodnú cestu, ktorá viedla z Topolčian do Nitry (Jančiová a i. 2019, 18). Od tohto obdobia do druhej polovice 15. storočia bol nepretržite obývaný, po roku 1406 výlučne rodom Aponiovcov. $V$ druhej polovici 15. a prvej polovici 16. storočia však hrad ostal v dôsledku majetkových sporov trvalejšie neobývaný. Intenzívnejší život sa tam vrátil až po polovici 16. storočia a z dôvodu tureckého nebezpečenstva $\mathrm{v}$ Uhorsku boli $\mathrm{v}$ tomto období realizované viaceré opravy aj prestavby hradu. Zanikol pravdepodobne v roku 1645 dôsledkom požiaru. Na začiatku 18. storočia slúžili hradné ruiny ako útočisko kuruckého vojska počas Rákociho povstania (Bóna/Repka/Sater 2017, 6-8).

Napriek záujmu o hrad už od 19. storočia a archeologickým prieskumom v roku 1981 a 2002, sa prvý archeologický výskum na hrade uskutočnil až v roku 2008 pod vedením Archeologického ústavu SAV v Nitre (Bielich 2011). Od roku 2015 realizovala na hrade systematický archeologický výskum Katedra archeológie FF UKF v Nitre, pod vedením D. Repku (Bóna/Repka/Sater 2017, 48). Tieto každoročné aktivity prinášajú nové poznatky o hradnej architektúre, ako aj o stavebnom vývoji Oponického hradu. Množstvo nálezov nájdených počas viacerých sezón výskumu vypovedá o každodennom živote hradného obyvatel'stva. Jedným z nich je aj kamenný žarnov, objavený počas výskumu v roku 2018 (obr. 1). Cielom nášho príspevku je ozrejmit’ funkciu neobvyklého žarnova na Oponickom hrade, ako aj priblížit využitie mlecích zariadení ${ }^{2}$ na stredovekých a novovekých hradoch.

1 Práca vznikla v rámci grantových projektov VEGA 2/0018/19 „Ekologické analýzy akulturácie krajiny Slovenska od mladšieho praveku dodnes“ a APVV-17-0063 „Vita intra muros - interdisciplinárny výskum hradov stredného Slovenska“.

2 Pod pojmom mlecie zariadenie rozumieme všetky druhy nástrojov a zariadenia k mletiu obilia, prípadne $\mathrm{k}$ mletiu alebo drveniu iných potravinárskych produktov a priemyselných surovín, vrátane rudy. V predmetnom období k tejto činnosti slúžili tzv. (ručné) rotačné mlynčeky, ktorých základným konštrukčným prvkom boli dva na seba položené kamene, žarnovy, ležiak a behúň (bližšie 


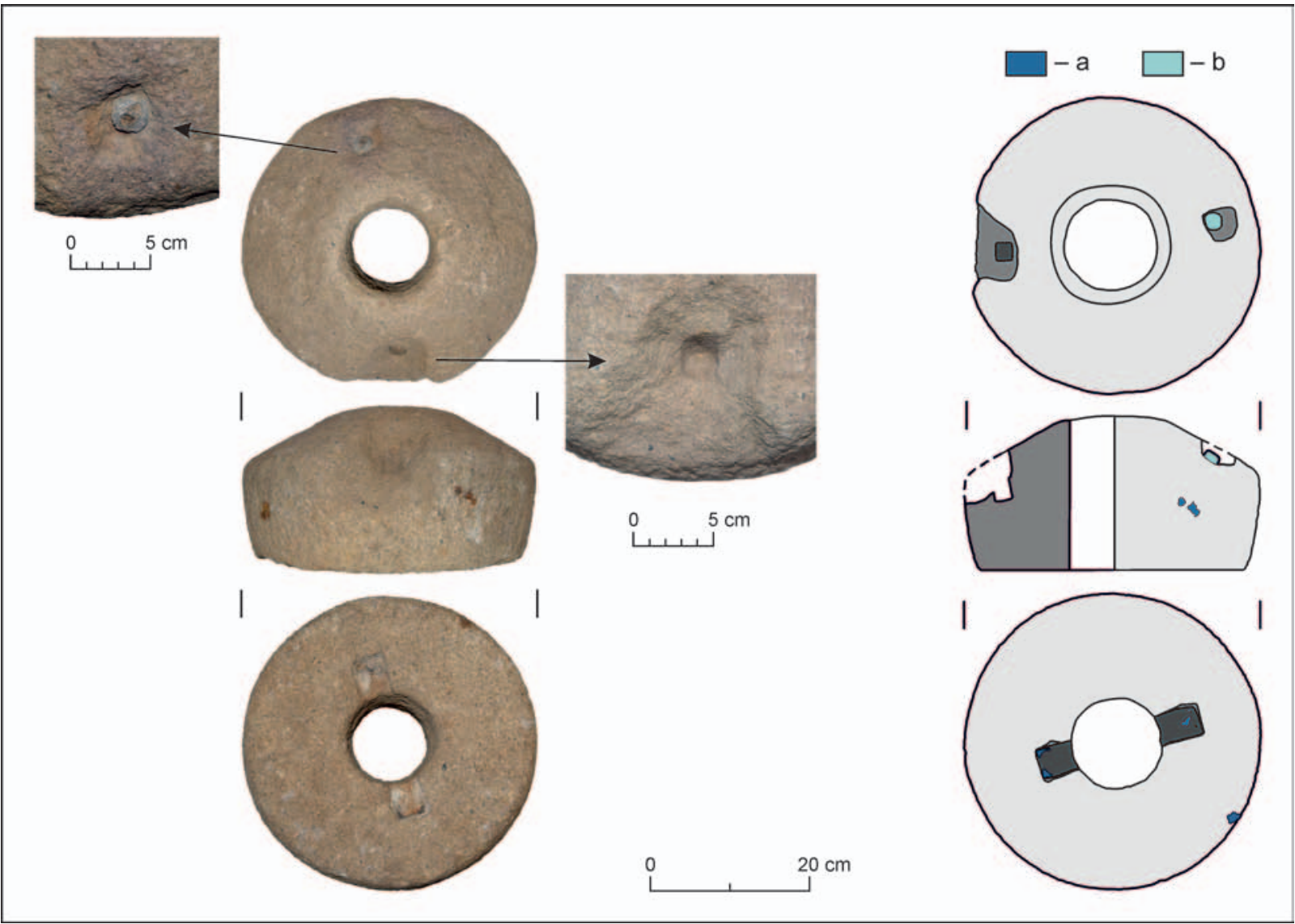

Obr. 1. Kamenný žarnov z Oponického hradu. Legenda: a - železo; b - olovo (?). Foto a kresba D. Repka.

\section{NÁLEZOVÉ OKOLNOSTI}

Kamenný žarnov bol nájdený pri úprave terénu počas sanačných prác $\mathrm{v}$ severnej časti hradného nádvoria (obr. 2), kde sa pri predpokladanom vstupe do hradu pôvodne nachádzal barbakan $\mathrm{v}$ tvare neukončeného pätuholníka. Žarnov bol zistený vo vrstve sutiny, ktorá bola tvorená deštrukciou kamenných hradných architektúr. Uvedené miesto bolo archeologicky doskúmané v roku 2020. Ďalšie časti rotačného mlynčeka identifikované neboli, našli sa tu len fragmenty keramiky a zvieracie kosti. Pod uvedenou vrstvou sutiny sa nachádzala d’alšia deštrukčná vrstva. Tá bola tvorená tehlami, keramickou dlažbou a hlavne kompletne zachovanými či rekonštruovatelnými kachlicami. Tieto nálezy ležali na ílovitej podlahe, ktorá predstavuje najmladšiu pôvodnú historickú úroveň využívanú do zániku hradu v polovici 17. storočia. $\mathrm{V}$ juhovýchodnom rohu daného priestoru bola dokonca

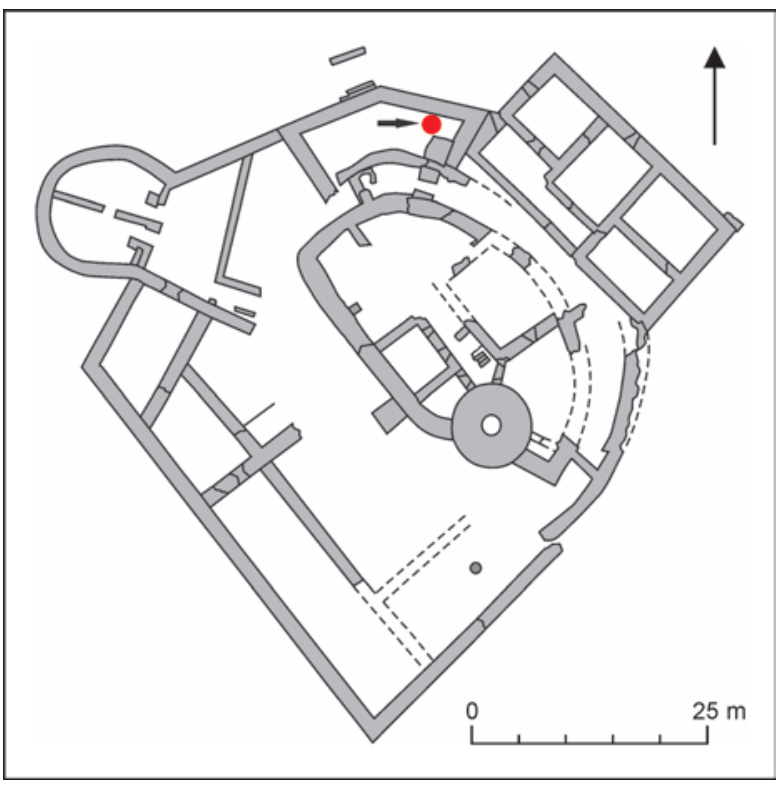

Obr. 2. Lokalizácia nálezu žarnova na Oponickom hrade. Autor D. Repka.

k téme v príspevku). Mlyn predstavuje technické zariadenie slúžiace $\mathrm{k}$ vyššie uvedeným aktivitám v našom prostredí od stredoveku. Jeho súčastou bol mlecí stroj, ktorého hlavnou konštrukčnou častou boli mlynské kamene (Beranová/Kubačák 2010, 115-127; Hanušin 1970, 193; Valaseková 2014, 47). Mlecie kamene predstavujú fragmenty bližšie nešpecifikovaného mlecieho zariadenia. 


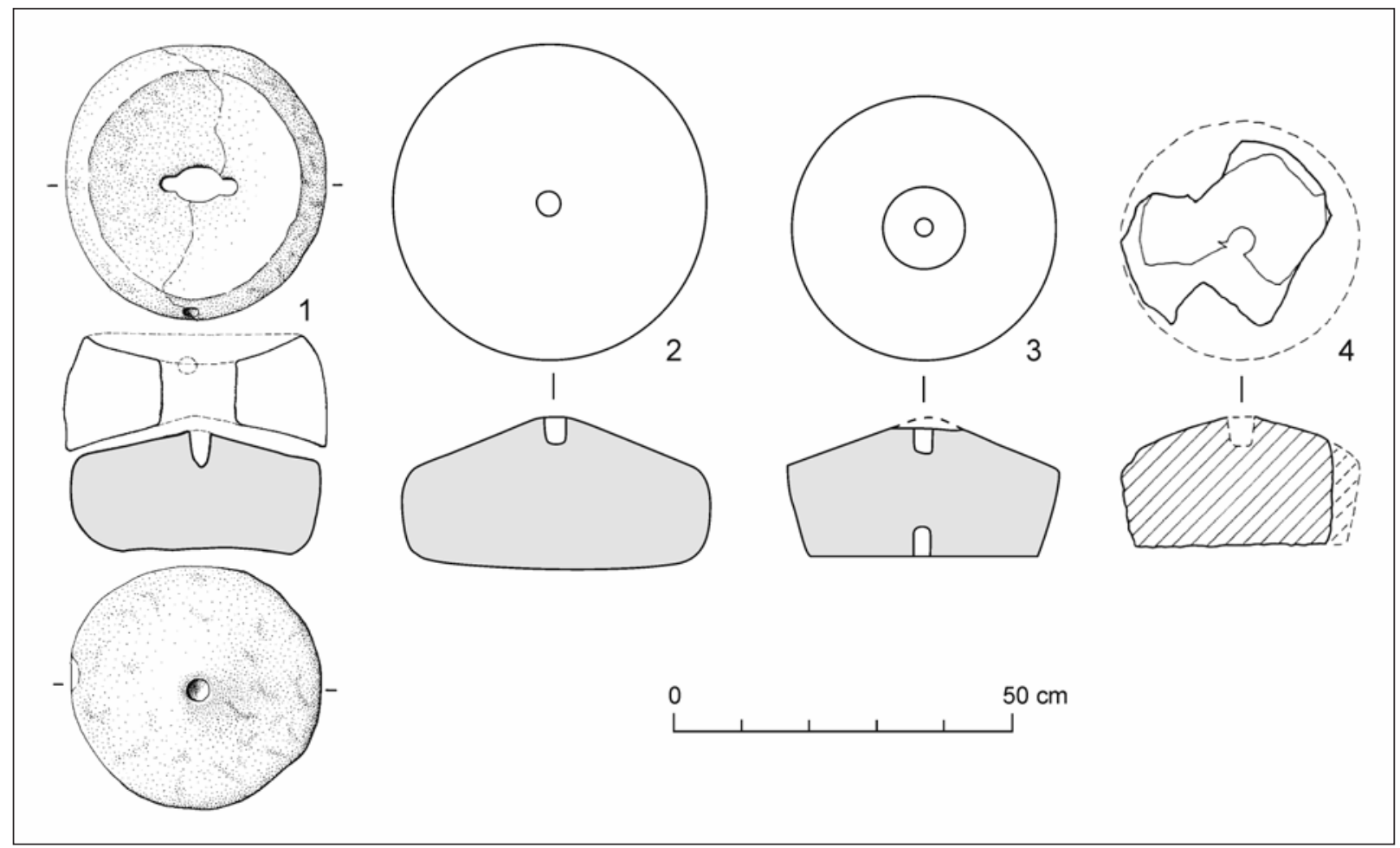

Obr. 3. Laténske žarnovy - ležiaky. 1 - Liptovská Mara (upravené podla Pieta 2008, 160, obr. 73: 5); 2, 3 - Třísov (upravené podla Fröhlich/Waldhauser 1989, 29, 5: 9: 11); 4 - Soběsuky (podl’a Holodňák/Mag 1999, 409, obr. 3: 1).

objavená kamenno-tehlová pec, ktorú možno v danom kontexte interpretovat’ ako pyrotechnologické zariadenie, slúžiace na vypalovanie kachlíc. ${ }^{3}$

\section{DESKRIPCIA}

Oponický nález predstavuje kamennú čast̉ mlecieho zariadenia, rotačného mlynčeka. Celkový tvar predmetného žarnova pripomína zrezaný kužel', z pohladu vertikálneho rezu možno hovorit o mierne asymetrickom tvare (obr. 1). Priemer žarnova je 36,4 cm, maximálna hrúbka je 18,2 cm, minimálna hrúbka $11 \mathrm{~cm}$ a hmotnost $24,8 \mathrm{~kg}$. V strednej časti plochy vo vertikálnom smere je prevŕtaný pravidelný stredový otvor naprieč celým žarnovom, s priemerom 10,4 cm. Na okraji vrchnej plochy boli do žarnova vytesané dve jamky, ktoré nie sú umiestnené $\mathrm{v}$ osi. V jednej z nich je zalomená kovová tyč s priemerom $2 \mathrm{~cm}$, druhá jamka s rozmermi 2,1 x 2,3 cm je zväčšená odštiepeným časti kameňa. Boky žarnova sú nahrubo otesané, mierne zaoblené. Na dvoch miestach bokov žarnova sme zaznamenali flaky skorodovaného kovu (železa?), umiestnené oproti sebe. V osi stredového otvoru boli vytesané drážky. Spolu vytvárajú plytkú obdížnikovú západku s vel'kostou 18,4 x 3,8 cm a hrúbkou $1,2-1,5 \mathrm{~cm}$. Povrch žarnova je mierne drsný, s mnohými menšími pórmi. Má svetlo ružovohnedú farbu, na miestach mechanického poškodenia (ošúchania) je farba ružovosivá. Vyrobený je z kremennej vulkanickej horniny, ryolitu. ${ }^{4}$

\section{ANALÝZA}

Nálezové okolnosti, tvar, surovina, ako aj viaceré konštrukčné znaky na predmetnom žarnove napovedajú, že jeho chronologické zaradenie a typové určenie nebude priamočiare.

3 Uvedená nálezová situácia s pecou bude publikovaná na inom mieste, v samostatnom príspevku.

4 Určila doc. RNDr. L'. Illášová, PhD., z Gemologického ústavu PF UKF v Nitre. 


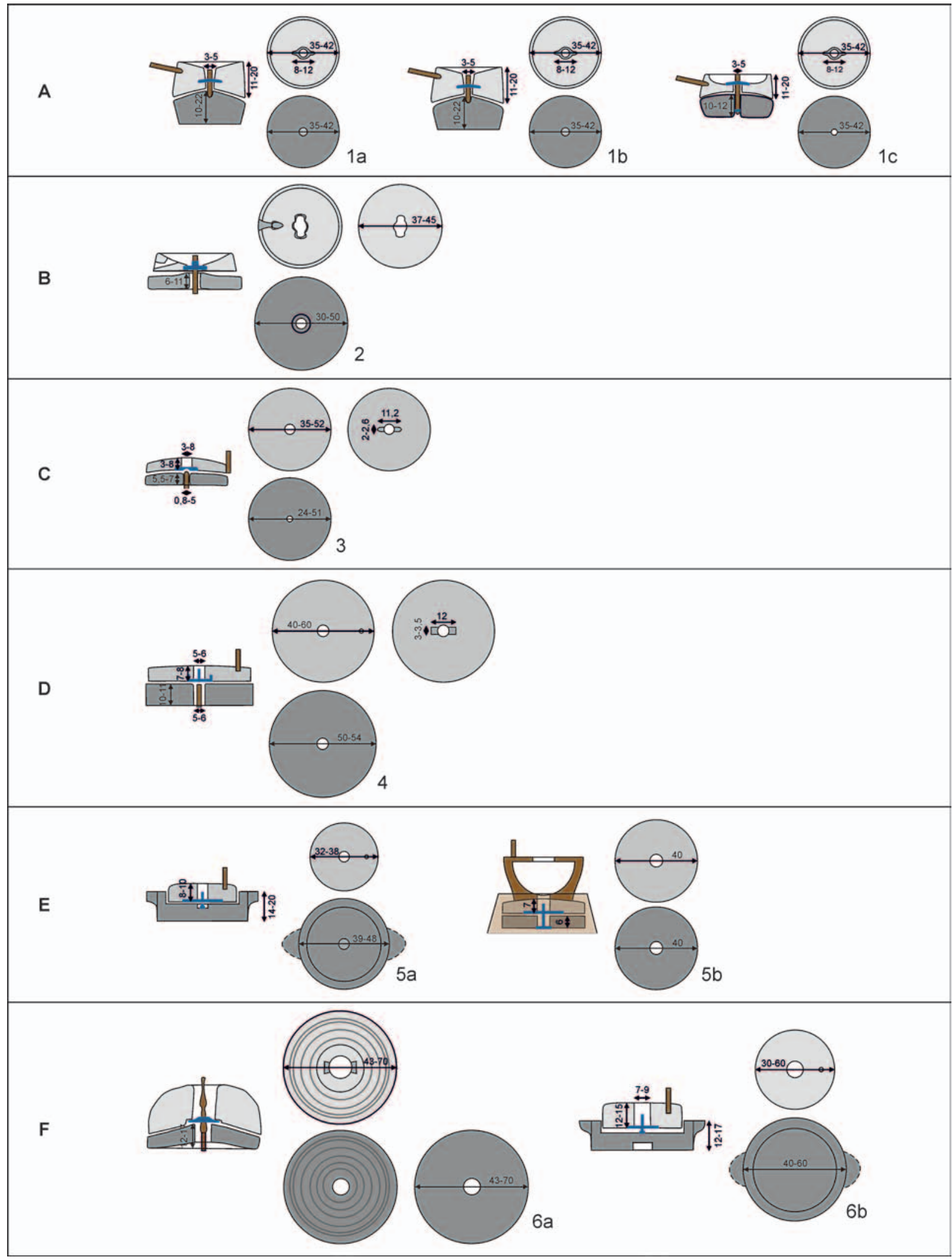

Obr. 4. Stručný prehl’ad vývoja ručných kamenných mlynčekov na území Slovenska od doby laténskej po novovek. A-E - obilné (A - doba laténska; B - doba rímska; C - včasný stredovek; D - vrcholný stredovek; E - novovek); F - rudné zo stredoveku, novoveku. Metrické údaje udávané v cm. Autor D. Repka (podla Beranová 1980; Halama/Zeman 2009; Hrubý a i. 2019; Mruškovič 1992; Waldhauser 1981, 181-184). 
Na základe celkového tvaru a metrických údajov by sme mohli predpokladat', že primárne ide o čast̉ laténskeho rotačného mlynčeka, konkrétne o laténsky ležiak (obr. 3; 4: A). Analogické exempláre sa objavujú od strednej doby laténskej (LTC) v širokom (stredo)európskom priestore. Známe sú predovšetkým z územia susedných Čiech (napr. Fröhlich/Waldhauser 1989, 23, 29, obr. 4: 7; 5: 9, 11; Holodňák/ Mag 1999, 408, 409, obr. 2: 6, 7; 3: 1, 2; Waldhauser 1981, 166-175, 189, 190, obr. 1: 2, 4; 2: 15, 18; 3: 23, 24; 5: 42; 7: 63; 8: 74; 10: 85) a Moravy (Čižmář/Leichmann 2007, 110, 121-125, s d’alšou literatúrou). Na Slovensku boli tvarovo a metricky podobné laténske ležiaky nájdené napríklad v Detve-Kalamárke (Šalkovský 2002, 120, obr. 20: 9), Liptovskej Mare (Pieta 2008, 160, obr. 73: 5), Plaveckom Podhradí-Pohanskej (Paulík 1976, 257, 258, tab. 55: 2; 56: 3) či Podturni (Hanuliak/Pieta 1977, 123, 124, 340, obr. 54: 8; Pieta 1982, 290, tab. XLVIII: 17). ${ }^{5}$

Uvedené analógie sú pritom na základe typológie vypracovanej J. Waldhauserom (1981, 181-184) radené $\mathrm{k}$ hrubším tvarom typu L2 so šikmými stenami (obr. 4: 1a) alebo typu L4 so zaoblenými stenami (obr. 4: 1b). Pri oboch typoch, však na rozdiel od nálezu z Oponického hradu, nie je stredový otvor pre os prevŕtaný skrz, ale iba čiastočne vyvŕtaný v horných partiách. Prevŕtané exempláre J. Waldhauser (1981, 184) zarad’uje do samostatného typu L6. Známe nálezy tohto typu sú však výraznejšie nižšie (max. hrúbka neprekračuje hodnotu 12,5 cm; obr. 4: 1c; napr. Březinová 2010, 117; Čambal/Bazovský 2017, 119, 125, tab. V: 7; Pieta 2008, 160, obr. 73: 4; Waldhauser 1981, 190) ako typy L2 a L4, resp. ako náš žarnov z Oponického hradu. Odlišnosti možno pozorovat' aj v neštandardne vel'kom priemere násypného otvoru exemplára z Oponíc, a to na úrovni 10,4 $\mathrm{cm}$. Na druhej strane pri uvedených laténskych analógiách sa pohybuje len $\mathrm{v}$ rozmedzí $3-5 \mathrm{~cm}$.

V nasledujúcom období sa na území juhozápadného Slovenska stretávame s používaním rotačných mlynčekov pozostávajúcich $\mathrm{z}$ dvoch žarnovov až po istom hiáte $\mathrm{v}$ závere staršej doby rímskej, ked’ na tomto území sídlil už germánsky kmeň Kvádov (Hajnalová/Varsik 2010, 188; Hečková/Repka 2019, 128, 129). V porovnaní s dobou laténskou sa však vytrácajú ležiaky s kónickou hornou častou. Navyše ani ich celková výška nedosahuje maximálne hodnoty laténskych exemplárov (obr. 4: 2), ku ktorým možno pri úrovni 18,2 cm radit aj nález z Oponického hradu. V dobe rímskej a stahovaní národov výška ležiakov len mierne prekračuje $10 \mathrm{~cm}$ (Hajnalová/Varsik 2010, 190, obr. 4: 3, 7, 12; Halama/Zeman 2009, 515, tab. 1; 2). O čosi väčšie hodnoty dosahujú behúne, avšak tie majú rovnako ako v dobe laténskej plochý tvar, v niektorých prípadoch aj s konkávnou násypnou priehlbňou (Hajnalová/Varsik 2010, 187, 190, tabela 2; obr. 4; Halama/Zeman 2009, 515, tab. 1; 2). Na druhej strane sa mierne zväčšuje priemer ležiakov aj behúňov, ktoré často presahujú úroveň $40 \mathrm{~cm}$ (obr. 4: 2; Hajnalová/Varsik 2010, 187, 190, tabela 2; obr. 4; Halama/Zeman 2009, 515, tab. 1; 2).

Neskôr sa rotačné mlynčeky objavujú vo včasnom stredoveku. Ich kamenné žarnovy sa však tvarovo ani vel'kostne nepodobajú analyzovanému exempláru (obr. 4: 3; napr. Beranová 1963; 2005, 283-286; Černohorský 1957; Janečka 2012; Macháček 2005; Marek/Skopal 2003; Valaseková 2015). To isté možno povedat' aj o vrcholnostredovekých (obr. 4: 4; Beranová 1975, 26, 27; Labuda 1988; Méri 1970, 76; Mlynka 2007, 57; Valaseková 2014, 35-38), novovekých (obr. 4: 5a, b; Mruškovič 1992) či rudných žarnovoch (obr. 4: 6a, b; Fajta 2015, 64-68; Fröhlich 1993; 2006; Kudrnáč 1973).

Na druhej strane musíme konštatovat, že oponický žarnov disponuje takými konštrukčnými znakmi, ktoré nie sú typické pre laténske exempláre. V prvom rade ide o vyhotovenie drážky pre osadenie/úchyt drevenej priečky, vzpierajúcej doštičky, vsadenej naprieč kruhového otvoru (Beranová 2005, obr. 85). Tento konštrukčný znak sa objavuje až vo včasnom stredoveku na behúňoch prevažne od 9. storočia (Beranová 1963, 192; Valaseková 2015, 112). Známy je aj z najstarších slovanských sídlisk (napr. Pleinerová 1975; Zeman 1976, 164), ako aj mimo sledovaný priestor, napríklad z územia dnešného Pol'ska už od 4.-5. storočia (Beranová 1980, 164). Drážky na behúňoch zo včasného stredoveku sú však kratšie a oblejšie ako na analyzovanom exemplári (Beranová/Kubačák 2010, 118, obr. 1: 2; Valaseková 2015, 113). Z vrcholného a neskorého stredoveku poznáme behúne s dlhšou drážkou obdížnikového alebo mierne vejárovitého tvaru (napr. Beranová 1963, 195; Nekuda 1975, 154, obr. 149; Olasz 1963, 2 , obr. 5). Aj pri niektorých typoch novovekých behúňov sa objavuje drážka na uchytenie priečky, avšak v tomto období možno hovorit’ o vel'kej variabilite typov a vyhotovení žarnovov (Mruškovič 1992; Valaseková 2011).

Najbližšie analógie k drážke pre úchyt priečky na skúmanom žarnove nachádzame na žarnovoch rudných rotačných mlynčekov. Tie sa objavujú vo vrcholnom stredoveku a v novoveku, kedy sa používali

\footnotetext{
5 Najnovší súpis nálezov laténskych žarnovov z územia Slovenska, ako aj Čiech a časti Rakúska podáva P. Horváth (2016, 87-99, mapa VI, VII) vo svojej nepublikovanej dizertačnej práci.
} 
na mletie rozdrvenej rudy na múčku (Fajta 2015, 64). Vel'mi podobné drážky možno sledovat na žarnove z rudného mlynčeka uloženom v stálej expozícii Slovenského banského múzea v Banskej Štiavnici. Drážku na spodnej časti behúňa tvoria dva otvory štvorcového prierezu $2 \mathrm{x}$ 2,5 cm s híbkou $3 \mathrm{~cm}$ (obr. 5: 1; Fajta 2015, tab. V). Ďalší exemplár, uložený v Depozitári technického oddelenia Slovenského banského múzea, má podobnú drážku, dokonca so zachovanou železnou doštičkou zapustenou do behúňa (obr. 5: 2; Fajta 2015, tab. X). Okrem analogického vyhotovenia drážky má oponický žarnov s prvým zmieneným banskoštiavnickým žarnovom velmi podobné aj iné sledované znaky, t. j. materiál, celkový tvar, priemer kotúča, povrch a opracovanie, ako aj vyhotovenie stredového otvoru (obr. 5: 1). Na rozdiel od rudných žarnovov nemá koncentrické kruhy. ${ }^{6}$

Stredový, resp. násypný otvor oponického žarnova s priemerom $10,4 \mathrm{~cm}$ prechádza cez jeho celé telo. Otvor prevŕtaný cez celú hrúbku kameňa sa objavuje vo včasnom stredoveku (Měřinsky 2002, 145), u ležiakov s priemerom od 0,8 po $5 \mathrm{~cm}$. V prípade behúňov je to od 3 do približne $8 \mathrm{~cm}$, najčastejšie však $4-5 \mathrm{~cm}$, pričom sa v niektorých prípadoch aj zužuje od vrchnej plochy k pracovnej ploche v priemere o 1,5-2 cm (Valaseková 2015, 112). Stredový otvor vrcholnostredovekých žarnovov je o niečo väčší ako v predchádzajúcom období (Valaseková 2014, 34), podobne je to aj pri novovekých (napr. Mruškovič 1992, 114), ako aj rudných žarnovoch (Fajta 2015; Fröhlich 2012). ${ }^{7}$

Dalším znakom na oponickom žarnove sú viaceré stopy po konštrukčnej časti slúžiacej k otáčaniu. Po bokoch žarnova možno sledovat’ stopy po skorodovanom kove (železe), ako aj viaceré vyšúchané plochy $\mathrm{v}$ týchto miestach (obr. 1: a). To vedie $\mathrm{k}$ predpokladu použitia rukoväte pripevnenej kolmo zboku a spevnenej železným pásom (obr. 6: 4). Tento spôsob otáčania žarnovom, behúňom, je typický pre včasnostredoveké rotačné mlynčeky, ktoré na rozdiel od analyzovaného exemplára boli menšie a lahšie (napr. Beranová 2005, obr. 27). Oponický žarnov je tak masívny, že zmienený spôsob otáčania v tomto prípade nie je pravdepodobný. Predpokladáme, že žarnovom sa otáčalo pomocou rúčky upevnenej $\mathrm{v}$ tele kameňa (obr. 6: 5, 6). Zmienený spôsob upevnenia rúčky $\mathrm{v}$ stredoeurópskom priestore poznáme z doby laténskej (napr. Beranová 2005, 283, obr. 84), neskôr až z vrcholného stredoveku (Valaseková 2014, 35, s d’alšou literatúrou). Zo stredoveku, ako aj z novovekých analógií poznáme ešte jeden spôsob otáčania, a to dvoma rukami pomocou dvoch oproti sebe umiestnených jamiek. Napriek tomu, že sa na oponickom žarnove nachádzajú dve jamky na osadenie rukoväte, nepredpokladáme súčasné využitie a mletie dvoma rukami, nakol'ko sa jamky nenachádzajú v jednej osi. Navyše, prvá jamka pravdepodobne nebola nikdy dokončená, pretože je vyhĺbená len plytko a nenesie stopy po vsadenej rúčke. Dokonca čast̉ kameňa v mieste jamky je odštiepená (obr. 1). Predpokladáme, že k poškodeniu žarnova došlo práve pri híbení jamky (obr. 6: 5). Následne bola pravdepodobne vyhĺbená d’alšia jamka. Tá obsahuje zvyšky sivého kovu (pravdepodobne olova), čo súvisí s upevnením rúčky v tomto mieste (obr. 1: b). Takéto vyhotovenie poukazuje na dva možné spôsoby otáčania behúňom. Prvým z nich je osadenie krátkej rúčky do tela behúňa (obr. 6: 6), ako v prípade vrcholnostredovekých, novovekých, či rudných rotačných mlynčekoch (obr. 5: 2; 7; Mruškovič 1992, 115, obr. 2). Druhou možnostou je osadenie dlhej drevenej páky, ktorej horná strana je pripevnená $\mathrm{k}$ trámu drevenej konštrukcie. Tento spôsob mletia poznáme zo stredoveku, napríklad z vyobrazenia svätej Hedvigy ako melie múku (Kovács 1981, obr. 2), ako aj z novovekej materiálnej kultúry (Kisbán 1980, 187; Mruškovič 1992, 117, obr. 4; Valaseková 2014, 217, tab. VI). Tak isto možno predpokladat zmienený spôsob pri ručných mlynčekoch na zlatú rudu (Fröhlich 1993, 17).

\footnotetext{
6 Tie možno identifikovat’ aj na d’alšom rudnom žarnove z obce Harta, ktorý sa však ešte v polovici minulého storočia používal k mletiu obilia a ktorý má tiež vel’mi podobnú drážku ako oponický (Valaseková 2015, 121).

7 Pri uvedených laténskych analógiách sa pohybuje len v rozmedzí $3-5 \mathrm{~cm}$.
} 


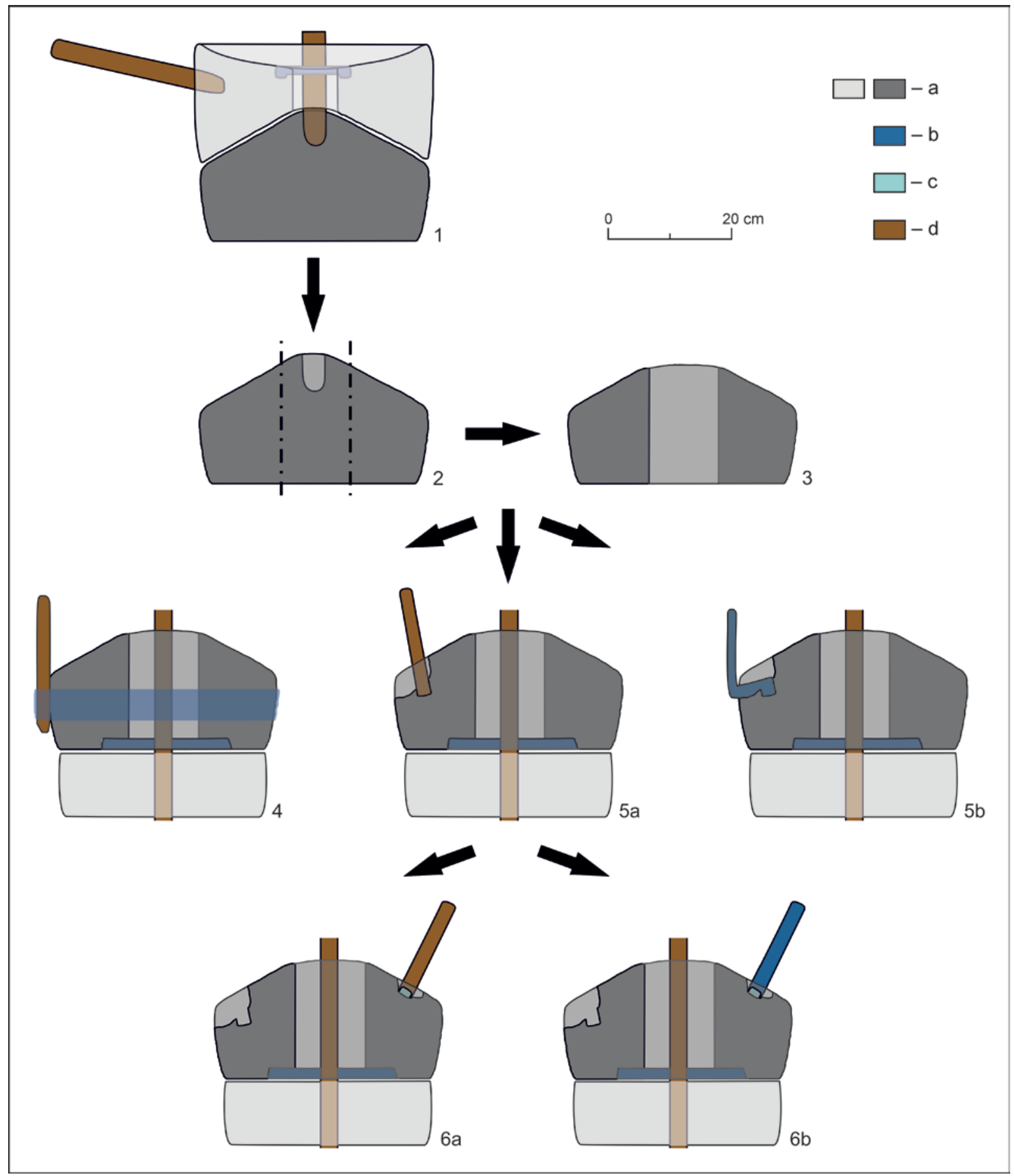

Obr. 6. Hypotetická transformácia žarnova z Oponického hradu. Laténsky ležiak prerobený na behúň v stredoveku/ novoveku. Legenda: a - kameň; b - železo; c - olovo (?); d - drevo. Autor D. Repka.

Z hladiska surovinového zloženia žarnova z Oponického hradu možno konštatovat', že ryolit sa na výrobu žarnovov na Slovensku (predovšetkým z okolia Žiaru nad Hronom, hlavne Kremnických a Štiavnických vrchov) používal bežne ako v dobe laténskej (Pieta 2008, 161; Slaná/Staneková 2014, 84), tak aj neskôr v stredoveku a novoveku (Bialeková/Klčo 1986, 63; Marek/Skopal 2003, 501; Pivko 2012, 618; Valaseková 2014, 33, 81). Výnimkou je v tomto ohlade doba rímska a stahovanie národov. Pri poslednom súpise nálezov žarnovov z územia juhozápadného Slovenska sa tu zastúpenie ryolitu neuvádza. Tento stav však môže byṫ spôsobený nízkym počtom exemplárov so surovinovým 
určením (Hajnalová/Varsik 2010, 188, 191). Na druhej strane sa o použití (stredoslovenského?) ryolitu v tomto období zmieňujú J. Halama a T. Zeman $(2009,510)$ v prípade nálezov zo susednej Moravy.

Na základe vyššie zmieneného rozboru tvarových znakov, metrických údajov a viacerých konštrukčných častí možno predpokladat', že oponický žarnov bol primárne vyrobený a používaný v dobe laténskej ako spodná čast’ rotačného mlynčeka, teda ako ležiak. $\mathrm{V}$ neskoršom období, v stredoveku alebo v novoveku, bol kameň opät použitý, tentokrát ako behúň. Svedčia o tom viaceré konštrukčné znaky, a to prehíbený a zväčšený násypný otvor, drážky na osadenie drevenej priečky, ako aj stopy po rukoväti, či železnej obruče na otáčanie behúňa (obr. 6). Tie nasvedčujú, že sa aj v mladšom období používal vo viacerých etapách.

Dôležitá otázka, ktorá vychádza z vyššie opísanej transformácie žarnova, nájdeného na Oponickom hrade je, ako a kedy sa tento pôvodne laténsky žarnov objavil v priestore vrcholnostredovekého až včasnonovovekého hradu. Stopy laténskeho osídlenia priamo $\mathrm{v}$ priestore hradného kopca neboli síce dosial' zistené, avšak bezprostredne pod ním evidujeme niekol'ko nálezov laténskej keramiky, a to v polohách Pod hradom a Od hradskej (Vanglová 2008, 213, č. 48, 49; Wiedermann 1985). Severozápadne od hradného kopca, na okraji intravilánu obce Oponice, v polohe Štátne majetky, boli dokonca z tohto obdobia objavené aj zahĺbené sídliskové objekty (Vangl'ová 2008, 213, č. 50).

Na základe uvedených dokladov laténskeho osídlenia nie je vylúčené, že tu v období existencie hradu našli starší laténsky ležiak, ktorý prispôsobili svojím potrebám. Kedy sa tak udialo, nie je isté. Hrad na základe písomných, stavebno-historických a najnovšie aj archeologických prameňov existoval približne 400 rokov. Prvá známa písomná zmienka o ňom pochádza z roku 1300. Jeho počiatky však možno klást už do obdobia 2. polovice 13. storočia (Repka/Sater 2019, 106, 107; Repka/Sater/Šimunková 2017, 201, 202), kedy bola v Uhorsku, po tatárskom vpáde, budovaná väčšina hradov. Zánik hradu bol dlhé roky spájaný s rokom 1645, kedy mal na hrade vypuknút požiar spôsobený úderom blesku. Uvedenú datáciu potvrdili najnovšie aj archeologické nálezy. Sutinové vrstvy preskúmané na hrade, ktoré obsahujú nálezy, sú datované do 17. storočia. Na základe chronologicky citlivejších artefaktov, ako sú mince či niektoré typy kachlíc, možno hovorit o období polovice 17. storočia. Na viacerých úsekoch hradu boli navyše zistené prepálené vrstvy a úrovne pôvodných ílom vymazaných podláh (Jančiová a i. 2019, 75; Repka/Sater 2019, 166, 167).

Z vyššie opísanej nálezovej situácie vyplýva, že oponický žarnov sa na hrade nachádza pravdepodobne v sekundárnej polohe. Do priestoru barbakanu sa dostal podla všetkého z horného hradu, a to v súvislosti so zánikom celého hradného komplexu v polovici 17. storočia.

\section{MLECIE ZARIADENIA NA HRADOCH A ICH SEKUNDÁRNE VYUŽITIE}

Mlecie zariadenia sa na hradoch objavujú v porovnaní s dedinským prostredím len ojedinele. V súvislosti s ich výskytom na hradoch sa vynára otázka ich funkcie a využitia.

O mletí obilia priamo na hrade možno uvažovat’ v prípade českého hradu Vizmburk, kde sa pri archeologickom výskume čiernej kuchyne podarilo odkryt niekolko žarnovov (obr. 8; Koštál 2013, 46, obr. 41; Stepán 2011, 5, 7, obr. 2). Takéto exempláre žarnovov alebo dokonca rotačných mlynčekov na hradoch nie sú častým nálezom, čo umocňuje predpoklad ich občasného využívania v hradnom prostredí. Podla viacerých bádatelov sa obilie na hrade takto mlelo len v núdzovom období, napríklad 


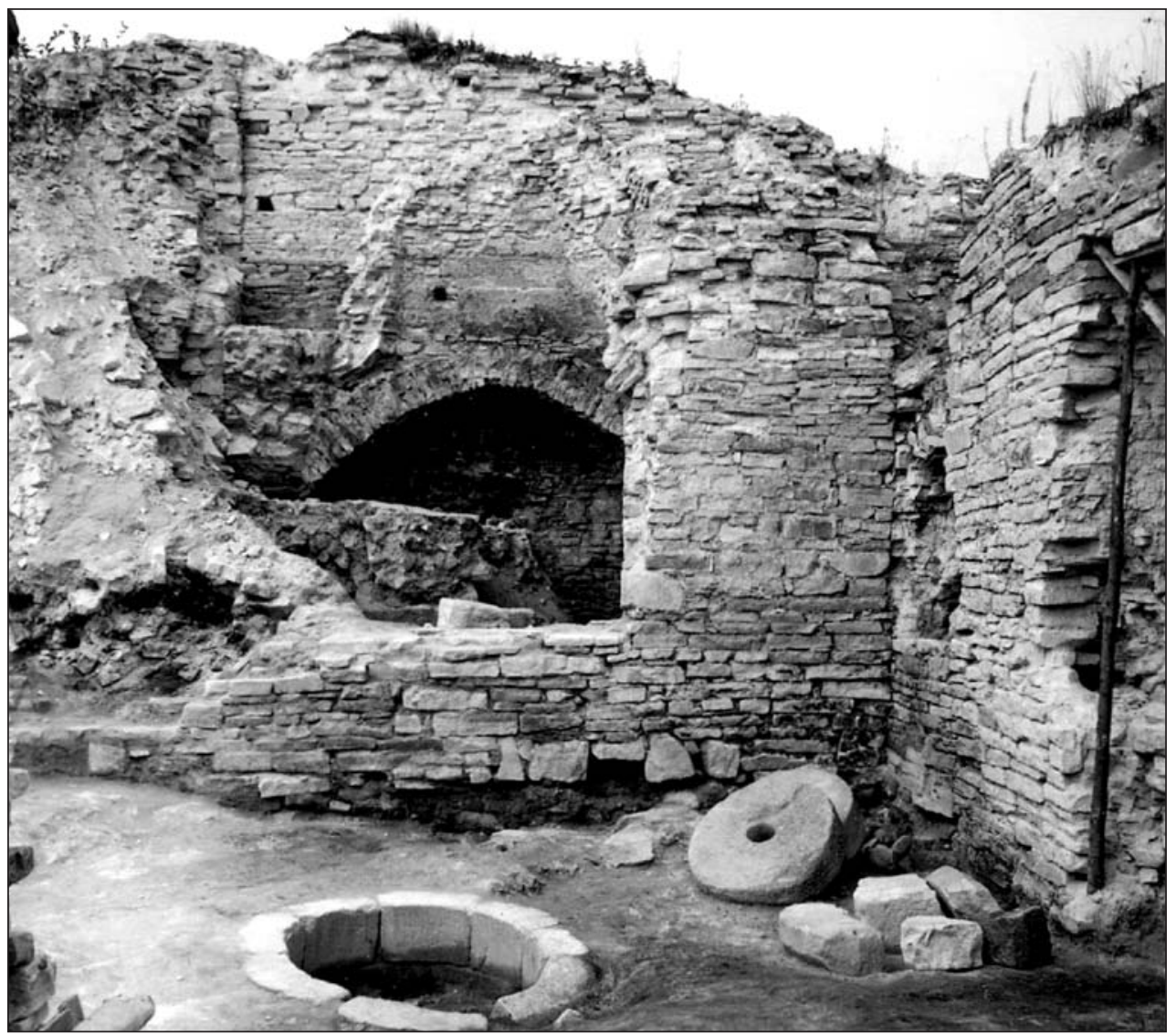

Obr. 8. Čierna kuchyňa s nálezmi žarnovov na hrade Vizmburk (podla Koštál 2013, 46, obr. 41).

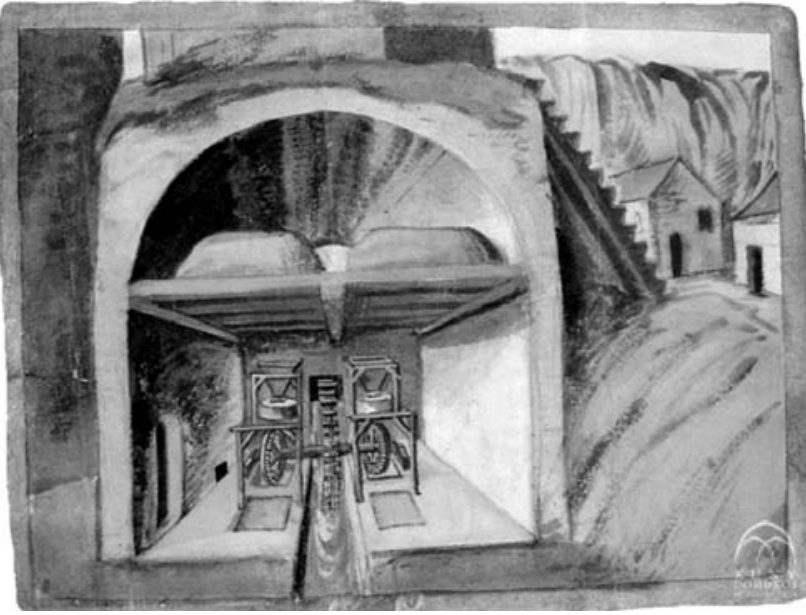

Obr. 9. Vyobrazenie mlynu na hrade Tata z roku 1587 (podla Bíró 1968). čom v uvedených prípadoch šlo o mlyny poháňané konskou silou, a teda o tzv. suché mlyny. Ďalšie suché mlyny sa uvádzajú aj v súvislosti s hradmi Krásna Hôrka či Slovenská L’upča (Mintálová-Zubercová 2009).

8 Počas tureckého obliehania bol v roku $1587 \mathrm{v}$ areáli hradu v Tate postavený mlyn z dvoch dôvodov. V prvom rade mal zabezpečovat' dostatok múky pre tu sídliace vojsko a v druhom rade bol určený na podnikanie s múkou (Bíró 1968, 313).

9 Jeden z dvojice mlynov mal slúžit na drvenie soli (Janura/Tihányiová/Šimkovic 2018, 234).

pri obliehaní hradu alebo počas dlhej vojny (Bíró 1968, 3138; ;anečka 2014, 15). V čase mieru mali obyvatelia hradu alebo panských sídiel zabezpečenú múku, ako aj obilie z okolitých panstiev (Domonkos 1991, 161; Vajkai 1983, 355).

Vyššie zmienenú teóriu vyvracia napríklad nález mlecích kameňov z hradu Filakovo. Tie sa našli v šachte, vo východnej časti horného hradu, ktorá slúžila ako obilnica, nad ktorou stál mlyn (Drenko 1981, 438; Tittonová 2018, 33, obr. 2), postavený v 16. storočí (Zemanová 2015, 21). Existencia mlynov na hradoch je archeologicky doložená v podobe ich kruhových či polygonálnych základov aj v prípade hradu

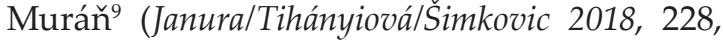
229, 231, 232, 242), Topolčianskeho (Bóna 2010, 134, 136), či Trenčianskeho hradu (Brunovský a i. 1991, 93; Menclová 1956, 119, 120). Ich činnost’ potvrdzujú aj dobové písomné pramene, pri- 
O existencii mlynov na hradoch poskytujú informácie aj ikonografické pramene. Na vyobrazení mad’arského hradu Tokaj z roku 1660 je v jeho areáli jasne viditelný mlyn (Végh 1966, 152, pozn. 145). Obdobnú situáciu možno pozorovat aj na d’alšom mad’arskom hrade Tata, kde bol vyobrazený mlyn z roku 1587 (obr. 9; Bíró 1968, 327).

Dalšou funkciou mlynov na hradoch je mletie pušného prachu. Jeden taký sa zachoval na hrade Boldogkő, na území dnešného Mad’arska, v tokajsko-zemplínskej oblasti. $\mathrm{V}$ jeho južnej veži boli objavené mlynské kamene, ako aj nádrž na vodu, ktorá súvisela s fungovaním mlecieho zariadenia (Jankovics/Koppány 2013, 137, obr. 1). Mlynské kamene boli okrem veži nájdené aj na viacerých iných miestach počas výskumu hradu. Existenciu tunajšieho mlyna na pušný prach zo 17. storočia dokladajú aj dobové písomné pramene (Végh 1966). Ďalší mlyn na Trebišovskom hrade sa spomína $\mathrm{v}$ súpise jeho majetku hradu z roku 1612 (Takáts 1915, 454). Mlyn na pušný prach z mad’arského hradu Regéc poznáme zase zo zmienky z roku 1632

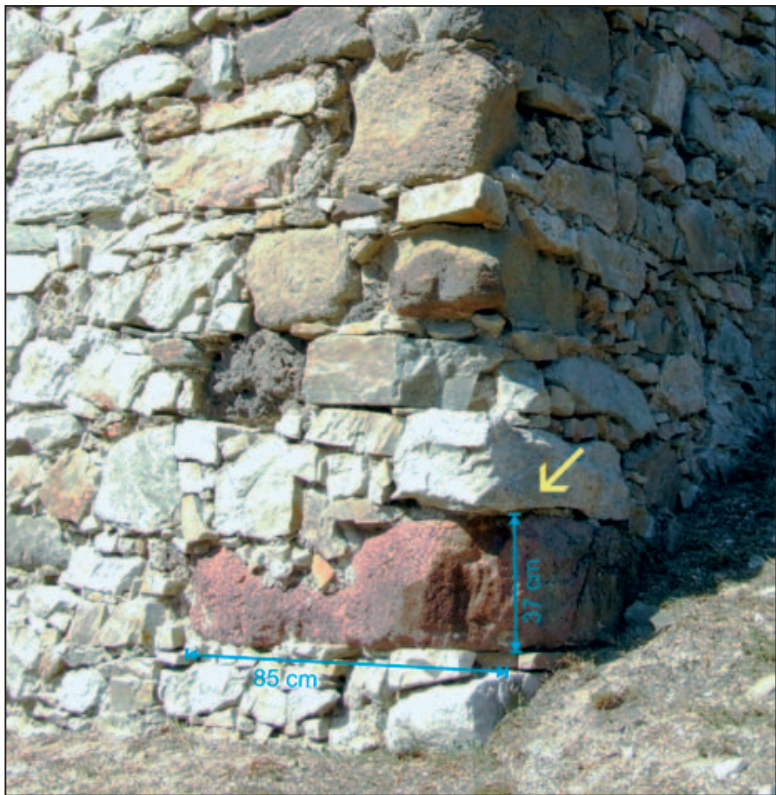

Obr. 10. Zamurovaný mlynský kameň v severovýchodnom nároží juhovýchodného paláca hradu Hrušov. Foto S. Blahová. (Végh 1966, 152). Dvojica mlynov na pušný prah je známa aj z vyššie spomínaného Trenčianskeho hradu. Jeden z nich stál na dolnom hrade pri kasárňach a druhý pri delovej bašte (Brunovský a i. 1991, 93; Menclová 1956, 119, 120).

Vo viacerých prípadoch sa však mlecie zariadenie, predovšetkým v podobe vodných mlynov, nenachádzalo priamo $\mathrm{v}$ areáli hradu, ale $\mathrm{v}$ jeho zázemí, o čom nás informujú predovšetkým písomné a kartografické pramene. V niektorých prípadoch sú aj fyzicky identifikované, ako napríklad pri českých hradoch Libštejn (Durdík 1983, 473), Strádová (Musil/Netolický 2015, 466, 467, obr. 10), Kvašov či Vrtba (Hobl/Kodera 2019, 69, 72-74, obr. 3; 5). Rovnaký doklad máme aj z hradu Nagyvázsony na území dnešného Madarska.

Okrem nálezových kontextov, ktoré vypovedajú o ich primárnej funkcii mletí obilia či iného materiálu (rúd, soli, pušného prachu) sa často stretávame s ich druhotným využitím. Masívne mlynské kamene alebo ich časti poskytovali vhodný stavebný materiál, preto ich nachádzame v múroch hradnej architektúry. Takýto doklad poznáme napríklad z nemeckého hradu Birchburg, kde boli v hradnom murive z 13.-14. storočia sekundárne použité mlecie kamene z rudného mlyna (Fröhlich 2012, 121). ${ }^{10}$ Ďalší, doposial' nepublikovaný doklad mlynského kameňa ako stavebného materiálu poznáme z hradu Hrušov. Tu sa v murive severovýchodného nárožia juhovýchodného paláca, datovaného do 16. storočia, nachádza sekundárne opracovaný exemplár vyrobený z pórovitého ružového ryolitu ${ }^{11}$ (obr. 10; 11: 7). O inom sekundárnom využití možno uvažovat' v súvislosti s rovnako nepublikovaným nálezom takmer kompletne zachovaného mlynského kameňa, nájdeného bezprostredne pri vstupe pred bránou, ktorá bola súčastou juhozápadného hradbového múru hradu Hrušov z druhej až tretej tretiny 15. storočia (obr. 11: 2). V tejto súvislosti možno predpokladat', že išlo o čast’ závažia padacieho mostu, ktorý sa tu pôvodne nachádzal. Takto použitý mlynský kameň bol vyrobený rovnako ako zamurovaný exemplár z ryolitu, s rozmermi a tvarom podobným ako boli mlynské kamene z iných stredovekých nálezísk. Okrem vyššie zmienených kameňov pochádzajú z hradu Hrušov aj dalšie fragmenty a časti mlynských kameňov a žarnovov z rotačných mlynčekov. Väčšinou boli nájdené v zásypoch $\mathrm{v}$ rôznych častiach hradu (obr. 11: 1, 3-6), čo neumožňuje jednoznačne určit ich funkciu. $\mathrm{V}$ prípade mlynských kameňov mohlo íst’ o stavebný materiál, podobne ako pri predchádzajúcich dvoch nálezoch. Tomu by nasvedčoval aj fakt, že v blízkosti hradu, v jeho širšom zázemí je známych

\footnotetext{
10 O širokom využití mlynských kameňov ako stavebného materiálu sa zmieňuje J. Fröhlich $(2012,123)$.

11 Určil doc. RNDr. D. Pivko, PhD., z Katedry geológie a paleontológie PF UK v Bratislave.
} 


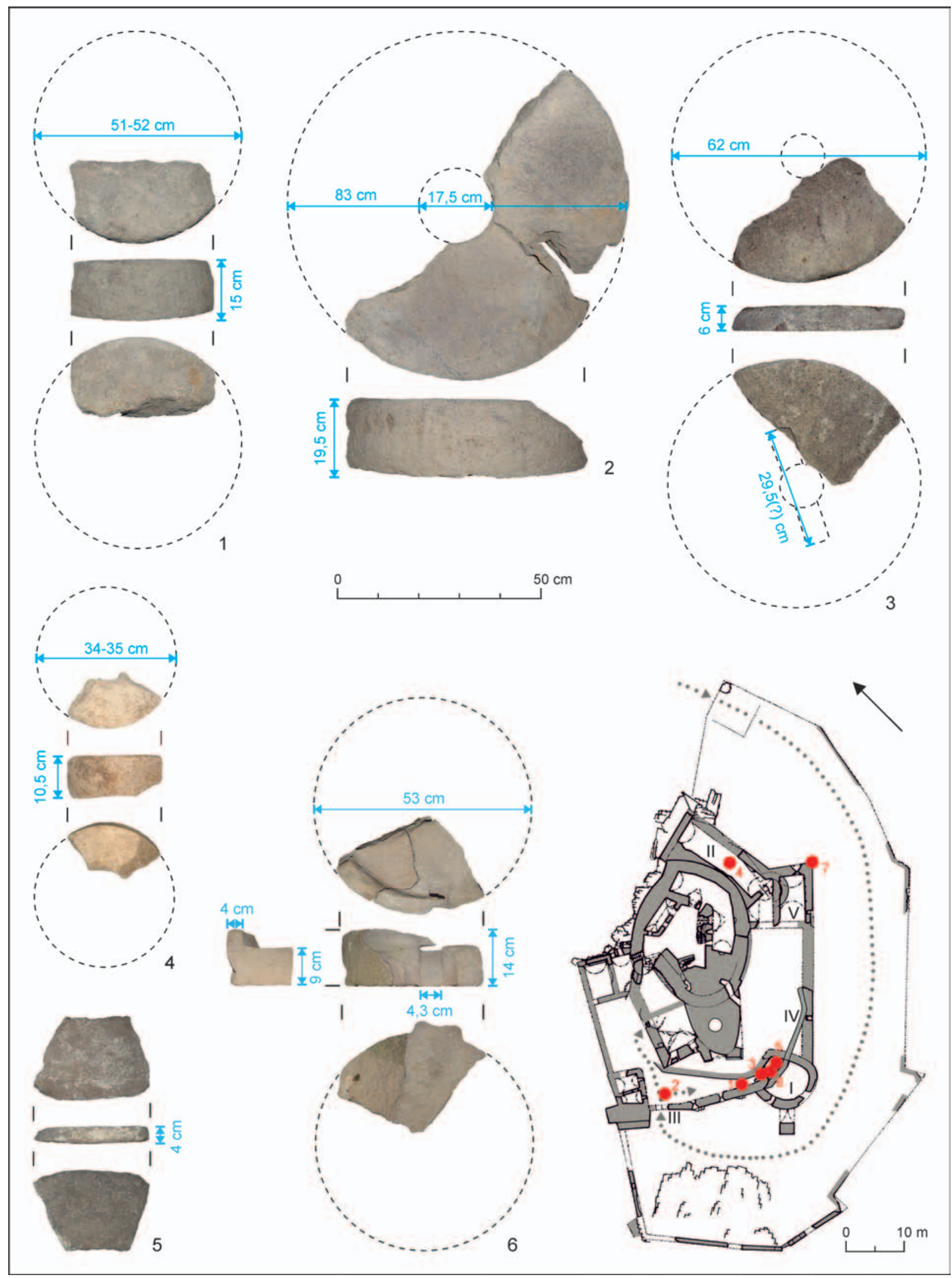

Obr. 11. Fragmenty mlecích kameňov z hradu Hrušov. 1-6 - na pláne hradu korešpondujú s číslovaním jednotlivých mlecích kameňov; 7 - zamurovaný mlynský kameň vyobrazený na obr. 10; I - delová bašta; II - východný palác; III - brána do 1. predhradia; IV - parkán; V - juhovýchodný palác. Foto a kresba D. Repka. 


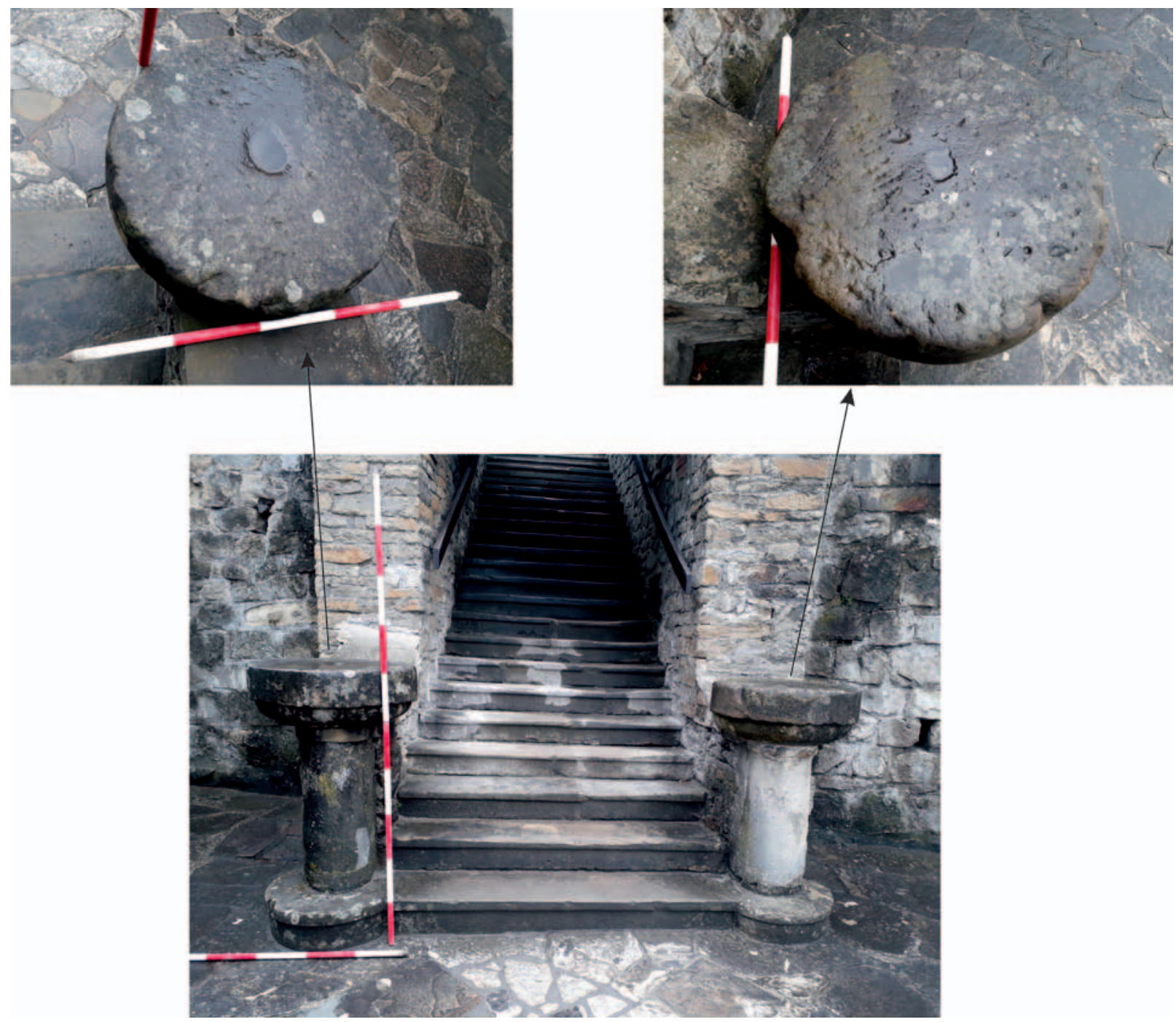

Obr. 12. Sekundárne využitie žarnovov ako hlavice ozdobných stĺpov zábradlia schodiska pri Thurzovom paláci na Oravskom hrade. Foto B. Lofajová Danielová.

z písomných prameňov, ako aj z mapových vyobrazení niekol'ko vodných mlynov. ${ }^{12}$ Tie, alebo čast’ z nich, mohli pracovat' aj pre potreby tunajšieho hradného obyvatel'stva. Porušené a nepotrebné kamene z mlynov mohli slúžit ako stavebný materiál pri stavbe, alebo obnove hradnej architektúry. Ostatné žarnovy mohli byt๋ súčastou rotačných mlynčekov použivaných na hrade, ako to bolo v prípade vyššie zmienených hradov. Mohli slúžit aj ako stavebný materiál a nie je vylúčená ani možnost' ich dvojakého využitia.

Druhotnú funkciu žarnovov môžeme vidiet aj na Oravskom hrade, kde sa použili ako hlavice ozdobných stĺpov zábradlia schodiska z 19. storočia na hlavnom nádvorí, ktorý viedol od terasy pri Thurzovom paláci ku terase pod Baštami a Korvínovým palácom (obr. 12). ${ }^{13}$

Špecifickým dokladom mlecích kameňov na hradoch je ich výroba. Tá je doložená napríklad na hornom hrade Pustého hradu vo Zvolene. Niekol'ko kusov žarnovov tu bolo nájdených v prízemí a suteréne obrannej bašty, kde sa pôvodne nachádzala remeselná dielňa (Beljak a i. 2014, 200; Hanuliak 2001, 188, 189).

12 Východne od hradu sa nachádzal skýcovský mlyn. Vodné mlyny sú známe aj z južne sa nachádzajúcej obce Hostie (2. vojenské mapovanie, Sec. 41, 42, Coll. XXIX). V obci Hostie sa pritom prvýkrát mlyn v písomných prameňoch spomína v roku 1720 (Benček 2011, 12).

13 Za informáciu d’akujeme Mgr. B. Lofajovej Danielovej z Oravského múzea P. O. Hviezdoslava v Dolnom Kubíne. 
Vo viacerých prípadoch, napríklad ako pri vyššie zmienenej časti žarnovov a mlynských kameňov z hradu Hrušov, nájdenej v interiéri paláca a delovej bašty, dalej z obytnej veže dolného hradu Pustého hradu vo Zvolene (Beljak a i. 2014, 62, 198, 199, obr. 153), či rovnako obytnej veže hradu Kost v Čechách (Štepán 2011, 5) atd’, však ich presnú funkciu nepoznáme.

\section{ÚVAHY NAD FUNKCIOU ŽARNOVA Z OPONICKÉHO HRADU}

Vel'kost’ a konštrukčné znaky oponického žarnova jednoznačne poukazujú na jeho funkciu ako behúňa, ktorý bol súčastou ručného rotačného mlynčeka. Ten mohol byt’ súčastou hradnej výbavy tunajšieho obyvatel'stva $\mathrm{v}$ prípade núdze (na mletie obilia alebo soli), ${ }_{1}^{14}$ nakol'ko predpokladáme, že sa v priestore hradu mlyn nenachádzal. Nezmieňujú sa o ňom písomné pramene, ani sa o ňom nedozvedáme z kartografických zdrojov, či dobových vyobrazení. ${ }^{15}$ Dobové pramene poskytujú len informácie o mlynoch v zázemí hradu. Na druhom vojenskom mapovaní (Sec. 42, Coll. XXVIII) z rokov 1819 až 1858 sú na území obce Oponice zakreslené dva vodné mlyny. Ďalšie poznáme z ned’alekých Podlužian, ktoré dnes patria do katastra obce Sulovce či susedných Kovariec (2. vojenské mapovanie, Sec. 41, Coll. XXVIII). O mlyne v Kovarciach, ktoré boli súčastou oponického hradného panstva sa zmieňujú aj dobové písomné pramene, a to už v roku 1490 (Marsina 1987, 367, 368).

Na základe nálezových okolností a faktu, že spolu s behúňom sa nenašiel aj ležiak, nemožno vylúčit ani možnost̉ jeho sekundárneho použitia na hrade. Analyzovaný artefakt sa mohol dostat na hrad už len ako „kameň”, ktorý mohol byt๋ využitý k stavebným aktivitám.

\section{LITERATÚRA}

Beljak a i. 2014

Benček 2011

Beranová 1963

Beranová 1975

Beranová 1980

Beranová 2005

Beranová/Kubačák 2010

Bialeková/Klčo 1986

Bielich 2011

Bíró 1968

Bóna 2010

Bóna/Repka/Sater 2017

Brunovský a i. 1991

Březinová 2010

Čambal/Bazovský 2017

Černohorský 1957

Čižmář/Leichmann 2007
J. Beljak/N. Beljak Pažinová/B. Beláček/M. Golis/J. Hunka/A. Krištín/V. Kohút/ P. Maliniak/M. Mordovin/M. S. Przybyla/D. Repka/M. Slámová/M. Šimkovic/ B. Tóth/O. Žaár: Pustý hrad vo Zvolene. Dolný hrad 2009-2014. Zvolen - Nitra 2014.

M. Benček: Z histórie obce Hostie 2. O panovníkoch a tureckých vpádoch. Hontianske novinky I/2. Hostie 2011.

M. Beranová: Pravěké žernovy v Československu. In: Vznik a počátky Slovanů IV. Praha 1963, 181-219.

M. Beranová: Zemědělská výroba v 11./14. století na území Československa. Praha 1975. M. Beranová: Zemědelství starých Slovanů. Praha 1980.

M. Beranová: Jídlo a pití v pravěku a ve středověku. Praha 2005.

M. Beranová/A. Kubačák: Dějiny zemédelství v Čechách a na Moravě. Praha 2010.

D. Bialeková/M. Klčo: Terénny prieskum v Pieštanoch-Kocuriciach. AVANS 1985, 1986, 63-65.

M. Bielich: Archeologický výskum delového bastiónu Oponického hradu. AVANS 2008, 2011, 67, 68 .

E. Bíró: Malomépítés Tatán 1587-ben. Komárom Megyei Múzeumok Közleményei 1, 1968, 311-327.

M. Bóna: Stavebné premeny Topol'čianskeho hradu. In: E. Wiedermann (ed.): Topol'čany vo vrstvách vekov. Topol'čany 2010, 121-144.

M. Bóna/D. Repka/P. Sater: Oponický hrad. Dejiny, výskum a obnova pamiatky. Nitra 2017. F. Brunovský/A. Fiala/T. Nešporová/M. Šišmiš: Trenčiansky hrad. Trenčín 1991.

G. Březinová: Sídlisko z neskorolaténskej polohy Zámeček v Šuranoch, Nitrianskom Hrádku. In: J. Beljak/G. Březinová/V. Varsik (ed.): Archeológia barbarov 2009. Nitra 2010, 113-130.

R. Čambal/I. Bazovský: Neskorolaténske sídliskové objekty v Bernolákove, okres Senec. Zbor. SNM 111. Archeológia 27, 2017, 109-131.

K. Černohorský: Žernovy v hospodářsko-společenském vývoji časného středověku. Památky archeologické 48, 1957, 495-545.

M. Čižmář/J. Leichmann: Pozdně laténské žernovy na Moravě. Památky archeologické 98, 2007, 109-128.

14 Jeho využitie na mletie rudy nepredpokladáme, keď̌̌e v blízkom okolí nie sú žiadne stopy po tažbe železnej rudy.

15 Dobové vyobrazenia ponúkajú pohl’ad len na ruiny hradu (porovnaj Bóna/Repka/Sater 2017, 43-47, obr. 44-47), z ktorých nie je možné identifikovat prípadnú existenciu mlyna. 
Domonkos 1991

Drenko 1981

Durdík 1983

Fajta 2015

Fröhlich 1993

Fröhlich 2006

Fröhlich 2012

Fröhlich/Waldhauser 1989

Hajnalová/Varsik 2010

Halama/Zeman 2009

Hanuliak 2001

Hanuliak/Pieta 1977

Hanušin 1970

Hečková/Repka 2019

Hobl/Kodera 2019

Holodñák/Mag 1999

Horváth 2016

Hrubý a i. 2019

Janečka 2012

Janečka 2014

Jančiová a i. 2019

Jankovics/Koppány 2013

Janura/Tihányiová/Šimkovic 2018

Koštál 2013

Kudrnáč 1973

Labuda 1988

Macháček 2005
O. Domonkos: Magyar néprajz nyolc kötetben 3. kötet. Anyagi kultúra 2. Kézművesség. Budapest 1991.

Z. Drenko: Fillakovský hrad. Archaeologia historica 6, 1981, 437-442.

T. Durdík: Hospodářské objekty a doklady výroby na hradech v povodí Berounky a severního Podbrdska. Archaeologia historica 8, 1983, 471-478.

M. Fajta: Fenomén vody v baníctve. Ryžovanie zlata, nálezy rudných mlynov na Slovensku. Diplomová práca. Ústav pre archeológiu. Karlova univerzita. Praha 2015. Nepublikované.

J. Fröhlich: Ruční mlýny na rozemílání zlaté rudy na Kometě. Rozpravy Národního technického muzea v Praze 125. Studie z dějin hornictví 22, 1993, 7-20.

J. Fröhlich: Archeologické doklady rudních mlýnů a stoup. In: J. Labuda (ed.): Montánna archeológia na Slovensku (25 rokov výskumu lokality Glanzenberg v Banskej Štiavnici). Banská Štiavnica 2006, 87-90.

J. Fröhlich: Stoupové a mlýnské kameny z rudných úpraven v Evropě. Mortarstones and millstones of ore treatment plants in Europe. Acta rerum naturalium 12, 2012, 119-125.

J. Fröhlich/J. Waldhauser: Př́íspěvky k ekonomice českých Keltů (kamenictví a distribuce žernovů). Archeologické rozhledy 91, 1989, 16-58.

M. Hajnalová/V. Varsik: Kvádske rolníctvo na Slovensku z pohladu archeológie a archeobotaniky. In: J. Beljak/G. Březinová/V. Varsik (ed.): Archeológia barbarov 2009. Hospodárstvo Germánov. Sídliskové a ekonomické štruktúry od neskorej doby laténskej po včasný stredovek. Archaeologica Slovaca Monographiae. Communicationes 10. Nitra 2010, 181-224.

J. Halama/T. Zeman: Nálezy žernovů z kontextů doby římské v Čechách a na Moravě. In: Archeologia barbarzyńców 2008. Rzeszów 2009, 479-530.

V. Hanuliak: Materiálne doklady remeselníckych dielní na Pustom hrade. Archaeologia historica 26, 2001, 185-191.

V. Hanuliak/K. Pieta: Výskum v Podturni v roku 1976. AVANS 1976, 1977, 123, 124.

J. Hanušin: Pojem a klasifikácia vodných mlynov na Slovensku (Príspevok ku štúdiu starých mlynov a mlynárstva I). Slovenský národopis 18, 1970, 177-222.

J. Hečková/D. Repka: Sídlisko z doby rímskej. In: P. Romsauer/J. Hečková/ D. Repka (ed.): Chotín VII. Sídlisko z doby halštatskej, rímskej a stredoveku. Nitra 2019, 49-141.

L. Hobl/P. Kodera: Hrad Vrtba a jeho hospodářské zázemí. Archaeologia historica 44, 2019, 65-87.

P. Holodňák/M. Mag: Vývoj mlecích zařízení a provenience surovin drtidel a žernovů v Soběsukách (okr. Chomutov, SZ Čechy). Mikrosonda do ekonomiky jednoho sídliště. Památky archeologické 90, 1999, 398-441.

P. Horváth: Hospodársko-výmenné vzt'ahy v strednej a neskorej dobe laténskej v strednom Podunajsku na základe distribúcie grafitovej keramiky a žarnovov. Dizertačná práca. Archeologický ústav SAV. Nitra 2016. Nepublikované.

P. Hrubý/M. Koštál/K. Malý/J. Těsnohlídek: Středověká úpravna rud u Koječína na Českomoravské vrchovině: k poznání technologií produkce stříbra ve státě posledních Přemyslovců. Archaeologia historica 44, 2019, 949-981.

J. Janečka: Kamenné žernovy z velkomoravského hradiště u Znojma. Bakalárska práca. Katedra histórie. Masarykova univerzita. Brno 2012. Nepublikované.

J. Janečka: Větrné mlynařství na Drahanské vrchovině. Diplomová práca. Katedra histórie. Masarykova univerzita. Brno 2014. Nepublikované.

B. Jančiová/D. Repka/P. Sater/M. Styk: Kachlice z Oponického hradu. Nitra 2019.

N. Jankovics/A. Koppány: A boldogkői vár újabb katatásának eredményei. In: M. Varga (ed.): Fiatal középkoros régészek IV. konferenciájának tanulmánykötete. Konferenciájának tanulmányai. Kaposvár 2013, 137-148.

J. Janura/M. Tihányiová/M. Šimkovic: Hrad Muráň z pohl’adu najnovšieho archívno-historického a architektonicko-historického výskumu. In: M. Kalinová (zost.): Najnovšie poznatky z výskumov stredovekých pamiatok na Gotickej ceste. Zborník Gotická cesta 2/2016. Rožňava - Bratislava 2018, 207-255.

J. Koštál (ed.): Vizmburk. Př́běh ztraceného hradu. Havlovice 2013.

J. Kudrnáč: Středověké úpravny zlaté rudy v Československu ve světle archeologických a písemných pramenů. Přehled o stavu zkoumání. Rozpravy Národního technického muzea v Praze 58. Studie z dějin hornictví 3, 1973, 20-30.

J. Labuda: Stredoveké osídlenie Sitna. Stredné Slovensko 7, 1988, 269-293.

J. Macháček: Raně středověké Pohansko u Břeclavi: munitio, palatium nebo emporium moravských panovníků? Archeologické rozhledy 56, 2005, 100-138. 
Marek/Skopal 2003

Marsina 1987

Menclová 1956

Méri 1970

Měřinsky 2002

Mintálová-Zubercová 2009

Mlynka 2007

Kisbán 1980

Mruškovič 1992

Musil/Netolický 2015

Nekuda 1975

Olasz 1963

Paulík 1976

Pieta 1982

Pieta 2008

Pivko 2012

Pleinerová 1975

Repka/Sater 2019

Repka/Sater/Šimunková 2017

Slaná/Staneková 2014

Šalkovský 2002

Štepán 2011

Takáts 1915

Tittonová 2018

Vajkai 1983

Valaseková 2011

Valaseková 2014

Valaseková 2015

Vanglová 2008

Végh 1966

Waldhauser 1981

Wiedermann 1985

Zeman 1976

Zemanová 2015
O. Marek/R. Skopal: Die Mühlsteine von Mikulčice. In: L. Poláček (Hrsg.): Studien zum Burgvwall von Mikulčice 5. Brno 2003, 497-590.

R. Marsina: Codex diplomaticus et epistolaris Slovaciae II. Bratislava 1987.

D. Menclová: Trenčiansky hrad. Bratislava 1956.

I. Méri: Árpád-kori falusi gabonaőrlő és kenyérsütő berendezések. Budapest 1970.

Z. Měřínsky: České země od př́chodu Slovanu po Velkou Moravu I. Praha 2002.

Z. Mintálová-Zubercová: Všetko okolo stola I. Martin 2009.

M. Mlynka: Ikonografické pramene k štúdiu slovenského pol’nohospodárstva. In: M. Válka a kol. (ed.): Agrární kultura. O tradičních formách zemědélského hospodáření a života na vesnici. Brno 2007, 43-62.

E. Kisbán: Kézimalom. In: Magyar Néprajzi Lexikon 3. Budapest 1980, 187-189.

Š. Mruškovič: Žarnovy - ručné rotačné mlyny na obilie z územia Slovenska v historickom a interetnickom kontexte. Zborník SNM 86. Etnografia 33, 1992, 93-148.

J. Musil/P. Netolický: Dokumentace reliktu předhradí hradu Strádová (okres Chrudim). Archaeologia historica 40, 2015, 457-473.

V. Nekuda: Pfaffenschlag. Zaniklá středovéká ves u Slavonic. Příspěvek k dějinám středověké vesnice. Brno 1975.

E. Olasz: Árpád kori malomkövek Karduskúton és Orosháza-Cinkuson. A Szántó Kovács János Múzeumi Évkönyve 1961-1962, 1963, 1-9.

J. Paulík: Keltské hradisko Pohanská v Plaveckom Podhradí. Martin 1976.

K. Pieta: Die Púchov-Kultur. Nitra 1982.

K. Pieta: Keltské osídlenie Slovenska. Nitra 2008.

D. Pivko: Stavebný a dekoračný kameň a jeho opracovanie na stredovekom Slovensku. Archaeologia historica 37, 2012, 609-628.

I. Pleinerová: Březno, vesnice proních Slovanů v severozápadních Čechách. Praha 1975.

D. Repka/P. Sater: Erb na kamennom článku z Oponického hradu. Pôsobenie Horváthovcov v rodinnom sídle Aponiovcov. Studia historica Nitriensia 23, 2019, 158-170.

D. Repka/P. Sater/K. Šimunková: Archeologické nálezy z Oponického hradu. Rozbor nálezov zistených počas sanácie hradu v rokoch 2001-2014 a archeologického výskumu v rokoch 2015-2016. Študijné zvesti Aú SAV 62, 2017, 181-206.

A. Slaná/Z. Staneková: Doklady pol’nohospodárstva púchovskej kultúry na území severozápadného Slovenska. In: Kelti na Slovensku. Zborník z konferencie 2014. Žilina 2014, 79-95.

P. Šalkovský: Výšinné hradisko v Detve - protohistorické osídlenie. Slovenská archeológia 50, 2002, 99-126.

L. Štepán: První středověké mlýny poháněné koly na vrchní vodu a jejich mlecí kameny. Archeologia technica 22, 2011, 5-10.

S. Takáts: Rajzok a törökök világából. Budapest 1915.

V. Tittonová: Archeologické výskumy a nálezy v katastri mesta Filakovo. In: M. Šesták (ed.): Zborník zo šturtého ročníka stretnutia priatelov regionálnej histórie. 24. novembra 2018. Hradište 2018, 32-38.

Zs. Vajkai: Malomtípusok és a molnár mesterség a 13. századi Magyarországon II. Magyar Mezőgazdasági Múzeum Közleményei 1981-1983, 1983, 349-370.

E. Valaseková: Archeologické doklady mletia obilia vo včasnom stredoveku. Bakalárska práca (Univerzita Konštantína Filozofa v Nitre). Nitra 2011. Nepublikované.

E. Valaseková: Nástroje k spracovaniu obilia v stredoveku na Slovensku. Diplomová práca (Univerzita Konštantína Filozofa v Nitre). Nitra 2014. Nepublikované.

E. Valaseková: Rotačné mlynčeky a ich úloha v pol'nohospodárstve včasného stredoveku. In: Z. Borzová (ed.): Interdisciplinárne o polnohospodárstve včasného stredoveku. Nitra 2015, 109-151.

T. Vanglová: Osídlenie severnej časti Nitrianskej pahorkatiny a pril’ahlých svahov Považského Inovca a Tribeča v dobe železnej. Śtudijné zvesti AÚ SAV 44, 2008, 203-217.

K. Végh: Boldogkő várának feltárása. A Hermann Ottó Múzeum Évkönyve 6, 1966, 109-170.

J. Waldhauser: Keltské rotační mlýny v Čechách. Památky archeologické 72, 1981, 153-221.

E. Wiedermann: Archeologické pamiatky Topol'čianskeho múzea. Materialia archaeologica Slovaca 7. Nitra 1985.

J. Zeman: Nejstarší slovanské osídlení Čech. Památky archeologické 67, 1976, 115-235. O. Zemanová: Filakovský hrad - kamenný svedok protitureckých bojov. Kontexty kultúry a turizmu 1, 2015, 19-24. 


\title{
The quern stone from the Oponice castle and discussion on the function of grinding tools at medieval and post-medieval castles
}

\author{
Dominika Repka - Zuzana Borzová - Stanislava Blahová
}

\author{
Summary
}

During sanation works in the northern part of the courtyard - barbican of Oponice castle $\left(2^{\text {nd }}\right.$ half of the $13^{\text {th }}$ century - mid-17 ${ }^{\text {th }}$ century), a quern stone was discovered in 2018 in a layer of debris consisting of collapsed architectural structures. It probably arrived in this area from the upper castle, in association with the extinction of the whole castle complex in the mid $17^{\text {th }}$ century (Jančiová a i. 2019, 75; Repka/Sater 2019, 166, 167).

The find context, shape, raw material as well as several construction features suggest that its chronological classification or typological identification will not be straightforward. The quern stone with diameter of $36.4 \mathrm{~cm}$, thickness of 11.0-18.2 cm and weight of $24.8 \mathrm{~kg}$ has a shape of a truncated cone (Fig. 1). The central hopper hole with diameter of $10.4 \mathrm{~cm}$ is drilled through the full thickness of the quern stone. On the edge of the upper surface, two dimples were carved in the quern stone. There is a broken metal rod with diameter of $2.0 \mathrm{~cm}$ in one of them, the other one with dimensions of $2.1 \times 2.3 \mathrm{~cm}$ was enlarged when a piece of stone was chipped off. Sides of the quern stone are roughly chiselled and slightly rounded. On the bottom part, two grooves are engraved in the axis of the central hopper hole. They make a shallow rectangular lock of $18.4 \times 3.8 \mathrm{~cm}, 1.2-1.5 \mathrm{~cm}$ thick. The above described quern stone is made of pink-brown rhyolite.

Based on the overall shape as well as the metric data, we can suppose that the quern stone was not manufactured during the existence of the medieval and post-medieval castle; it was primarily a quern from a La Tène rotary mill (Fig. 3; 4: A). Analogous exemplars which could be classified into type L2 with oblique walls or type L4 with rounded walls (Waldhauser 1981, 181-184) occur in the wide (central) European territory since the Middle La Tène period (LTC stage).

On the other hand, we must state that the quern stone form Oponice castle has construction elements typical of the above mentioned La Tène exemplars. Firstly, there is the rectangular groove for inserting/attaching a wooden millrind (Fig. 1). A similar shape is known from the High and Late Middle Ages (Beranová 1963, 195; Nekuda 1975, 154, fig. 149; Olasz 1963, 2, fig. 5) or the post-medieval period (Mruškovič 1992; Valaseková 2011). The nearest analogies to the groove on the studied quern stone used for attaching a millrind are found on quern stones used for grinding ores in these periods (Fig. 5: 1, 2; Fajta 2015, pl. V; X). Besides the groove, the quern stone from Oponice has other similar features too, i. e. material, overall shapes, diameter of the disc, surface and its finish as well as the design of the central hopper hole. Unlike quern stones for ore, it does not have concentric circles.

Other features present on the quern stone from Oponice include multiple traces of the construction part used for rotation. On the edges of the quern stone, we can observe traces of corroded metal (iron) and worn spots (Fig. 1: a). This leads us to the assumption that a handle was attached perpendicularly from the side and fastened by an iron band (Fig. 6: 4), which is typical of Early medieval rotary mills (e. g. Beranová 2005, fig. 27). The quern stone from Oponice castle is so massive that the above described way of rotation is not very probable. We suppose that the quern stone was rotated by means of a handle attached in the body of the stone (Fig. 6: 5, 6). Such method is known from the La Tène period (e. g. Beranová 2005, 283, fig. 84), later from the High Middle Ages (Valaseková 2014, 35). Moreover, the first slot was probably never finished as it is very shallow and does not bear any traces of an inserted handle. Part of the stone has even been chipped off the slot (Fig. 1). Later, another slot was made. It contains remains of a grey metal (probably lead), which is associated with a handle attached there (Fig. 1: b). Such design suggests two possible methods of rotating the muller. One involves a short handle inserted in the body of the muller (Fig. 6: 6), like in High medieval, post-medieval or ore rotary mills (Fig. 5: 2; 7; Mruškovič 1992, 115, fig. 2). Another one involves a long wooden shaft with its upper part attached to a beam of a wooden construction (Fröhlich 1993, 17; Kovács 1981, fig. 2; Kisbán 1980, 187; Mruškovič 1992, 117, fig. 4; Valaseková 2014, 217, pl. VI).

Based on the above mentioned analysis of design features, metrical data and several construction parts, we can assume that the quern stone from Oponice was primarily made and used in the La Tène period as the lower part of a rotary mill, i. e. a quern stone. Later, in the Middle Ages or the post-medieval period, the stone was used again, as a muller this time. This is documented by several construction features; it was used in several stages (Fig. 6). On the basis of the find context, we can suppose that it was part of the castle equipment of the local people, possibly in case of danger, since known archaeological, written, iconographic or cartographic sources have not confirmed existence of a mill at the castle itself. On the other hand, as no quern stone was found with the muller, we cannot exclude its possible secondary use at the castle. The analysed artefact could have arrived at the castle only as a "stone" used for construction.

Grinding tools occur at castles - compared to villages - only rarely and their functions are various. Firstly, there is association with grinding cereals (e. g. Fil'akovo castle: Drenko 1981, 438; Tittonová 2018, 33, fig. 2; Vizmburk castle: Fig. 8; Koštál 2013, 46, fig. 41; Štepán 2011, 5, 7, fig. 2). According to several researchers, cereals were ground at the castles only in case of emergency, e. g. during a siege of the castle or during long wars (Bíró 1968, 313; Janečka 2014, 15). Rare 
existence of mills at castles has been archaeologically confirmed also in form of circular or polygonal foundations (e. g. Muráň castle: Janura/Tihányiová/Šimkovic 2018, 228, 229, 231, 232, 242; Topolčany castle: Bóna 2010, 134, 136; Trenčín castle: Brunovský a i. 1991, 93; Menclová 1956, 119, 120). Other mills are reported in association with Krásna Hôrka castle or Slovenská Lupča castle (Mintálová-Zubercová 2009). Information on their existence at castles, such as Hungarian castles of Tokaj (Végh 1966, 152, note 145) and Tata (Fig. 9; Bíró 1968, 327), is also provided by iconographic sources. Other functions of grinding devices at castles included grinding of salt (e. g. Muráň castle: Janura/Tihányiová/Šimkovic 2018, 234) or gun powder (e. g. Boldogkő castle: Végh 1966; Regéc castle: Végh 1966, 152; Trebišov castle: Takáts 1915, 454; Trenčín castle: Brunovský a i. 1991, 93; Menclová 1956, 119, 120).

Besides find contexts documenting their primary function, i. e. grinding of cereals or other material (ores, salt, gun powder), we often come across their secondary use. Massive millstones or their parts often provided suitable construction material, so we can find them in walls of castle architecture (Fig. 10; 11: 7; Fröhlich 2012, 121). Their secondary use can be considered also in association with the find of a completely preserved millstone found immediately next to the entrance in front of the gate which was part of the southwestern curtain wall of Hrušov castle (Fig. 11: 2). Here, we can assume that it was part of the weight of a drawbridge which was originally located here. Quern stones' secondary function can be observed also at Orava castle, where they were used as heads of decorative columns of staircase railings from the $19^{\text {th }}$ century at the main courtyard leading from the terrace near Thurzo's palace to the terrace under the Bastions and Corvinus' palace (Fig. 12). Their production is a specific document of grinding stones. It has been documented for instance at the Upper castle of Pustý hrad castle in Zvolen (Beljak a i. 2014, 200; Hanuliak 2001, 188, 189).

Fig. 1. Quern stone form Oponice castle. Legend: a - iron; b - lead (?). Photo and drawing D. Repka.

Fig. 2. Location of discovery of the quern stone at Oponice castle. Author D. Repka.

Fig. 3. La Tène quern stones - querns. 1 - Liptovská Mara (modified according to Pieta 2008, 160, fig. 73: 5); 2, 3 - Tř́ísov (modified according to Fröhlich/Waldhauser 1989, 29, 5: 9: 11); 4 - Soběsuky (according to Holodňák/Mag 1999, 409, fig. 3: 1).

Fig. 4. Brief review of development of manual stone mills in the territory of Slovakia from the La Tène period to the postmedieval period. A-E - for cereals (A - La Tène period; B - Roman period; C - Early Middle Ages; D - High Middle Ages; E - post-medieval period); F - for ores from the Middle Ages, post-medieval period. Metrical data given in cm. Author D. Repka (according to Beranová 1980; Halama/Zeman 2009; Hrubý a i. 2019; Mruškovič 1992; Waldhauser 1981, 181-184).

Fig. 5. Grinding stones for ores deposited in the Slovak Mining Museum in Banská Štiavnica (according to Fajta 2015, pl. V; X).

Fig. 6. Hypothetical transformation of the quern stone from Oponice castle. La Tène quern transformed into a muller in the Middle Ages/postmedieval period. Legenda: a - stone; b - iron; c - lead (?); d - wood. Author D. Repka.

Fig. 7. Post-medieval rotary mill from the permanent exhibition of the Hungarian Museum of Ethnography in Budapest. No scale. Photo Z. Borzová.

Fig. 8. Black kitchen with finds of quern stones at Vizmburk castle (according to Košt’ál 2013, 46, fig. 41).

Fig. 9. Image of the mill at Tata castle from 1587 (according to Biró 1968).

Fig. 10. Quern stone incorporated in masonry on the north-eastern corner of the south-eastern palace of Hrušov castle. Photo S. Blahová.

Fig. 11. Fragments of quern stones from Hrušov castle. 1-6 - on the plan of the castle correspond with the numbers of individual grinding stones; 7 - the quern stone from the masonry depicted in Fig. 10; I - cannon bastion; II - eastern palace; III - gate to the first bailey; IV - zwinger; V - south-eastern palace. Photo and drawing D. Repka.

Fig. 12. Secondary use of quern stones as heads of decorative columns of staircase railings near the Thurzo's palace at Orava castle. Photo B. Lofajová Danielová.

Translated by Mgr. Viera Tejbusová

Mgr. Dominik Repka, PhD.

Katedra archeológie

Univerzita Konštantína Filozofa v Nitre

Hodžova 1

SK - 94974 Nitra

drepka@ukf.sk

Mgr. Stanislava Blahová

OZ LEUSTACH

Willermova 8

SK - 94907 Nitra-Janíkovce

s.blahova@gmail.com doc. Mgr. Zuzana Borzová, PhD.

Katedra archeológie

Univerzita Konštantína Filozofa v Nitre

Hodžova 1

SK - 94974 Nitra

zborzova@ukf.sk 
